Bone. 2014 October ; 67: 139-144. doi:10.1016/j.bone.2014.06.036.

\title{
Nicotinamide treatment in a murine model of familial tumoral calcinosis reduces serum Fgf23 and raises heart calcium
}

\author{
Austin M. Reilly ${ }^{\mathrm{a}}$, Amie K. Gray ${ }^{\mathrm{a}}$, Sharon M. Moe ${ }^{\mathrm{a}, \mathrm{b}}$, and Shoji Ichikawa ${ }^{\mathrm{a}}$ \\ aDepartment of Medicine, Indiana University School of Medicine, Indianapolis, Indiana 46202 \\ ${ }^{\text {b} R o u d e b u s h ~ V e t e r a n ~ A d m i n i s t r a t i o n ~ M e d i c a l ~ C e n t e r, ~ I n d i a n a p o l i s, ~ I n d i a n a ~} 46202$
}

\section{Abstract}

Mutations in the GALNT3 gene result in familial tumoral calcinosis, characterized by persistent hyperphosphatemia and ectopic calcific masses in soft tissues. Since calcific masses often recur after surgical removal, a more permanent solution to the problem is required. Nicotinamide is reported to lower serum phosphate by decreasing sodium-dependent phosphate co-transporters in the gut and kidney. However, its effectiveness in tumoral calcinosis remains unknown. In this study, we investigated nicotinamide as a potential therapy for tumoral calcinosis, using a murine model of the disease-Galnt 3 knockout mice. Initially, five different doses of nicotinamide were given to normal heterozygous mice intraperitoneally or orally. Treatment had no effect on serum phosphate levels; however, serum levels of a phosphaturic hormone, fibroblast growth factor 23 (Fgf23), decreased in a dose-dependent manner. Subsequently, high-dose nicotinamide (40 mM) was tested in Galnt 3 knockout mice fed a high phosphate diet. The radiographic data pre- and post-treatment showed that nicotinamide did not reverse the calcification. However, the treatment retarded calcification growth after four weeks, while in the untreated animals, calcifications increased in size. The therapy did not affect serum phosphate levels, but intact Fgf23 decreased in the treated mice. The treated mice also had increased calcium in the heart. In summary, nicotinamide did not alter serum phosphate levels, likely due to compensatory decrease in Fgf23 to counteract the phosphate lowering effect of nicotinamide. Although increased calcium accumulation in the heart is a concern, the therapy appears to slow down the progression of ectopic calcifications.

\section{Keywords}

calcification; Fgf23; nicotinamide; phosphate; tumoral calcinosis

(C) 2014 Elsevier Inc. All rights reserved.

Address all correspondence and requests for reprints to: Shoji Ichikawa, Ph.D., Department of Medicine, Division of Endocrinology and Metabolism, Indiana University School of Medicine, 541 N Clinical Dr, CL 459, Indianapolis, IN 46202, Phone: +1(317) 278-1787, Fax: +1(317) 278-0658, ichikawa@iu.edu.

Disclosure statement: The authors have no disclosures related to this project.

Publisher's Disclaimer: This is a PDF file of an unedited manuscript that has been accepted for publication. As a service to our customers we are providing this early version of the manuscript. The manuscript will undergo copyediting, typesetting, and review of the resulting proof before it is published in its final citable form. Please note that during the production process errors may be discovered which could affect the content, and all legal disclaimers that apply to the journal pertain. 


\section{Introduction}

Familial tumoral calcinosis is characterized by hyperphosphatemia and inappropriately normal or elevated 1,25-dihydroxyvitamin $\mathrm{D}\left[1,25(\mathrm{OH})_{2} \mathrm{D}\right]$, leading to ectopic calcifications in soft tissues. The genetic cause of this disease is a biallelic mutation in either of the three genes: GALNT3 [1-3], KL [4], or FGF23 [5, 6]. However, the majority of the patients have mutations in GALNT3 [2]. GALNT3 encodes a glycosyltransferase, GalNAc transferase 3, which $O$-glycosylates a phosphaturic hormone, fibroblast growth factor 23 (FGF23) to allow secretion of intact FGF23 [7]. Secreted FGF23 will form a complex with fibroblast growth factor receptors and co-receptor, Klotho, in the kidney [8,9], to promote phosphate excretion and inhibit $1,25(\mathrm{OH})_{2} \mathrm{D}$ biosynthesis [10]. Therefore, compromising any of the three proteins jeopardizes proper renal phosphate excretion and $1,25(\mathrm{OH})_{2} \mathrm{D}$ synthesis.

Inactivating GALNT3 and $F G F 23$ mutations render FGF23 proteins susceptible to proteolysis by subtilisin-like proprotein convertases, and most FGF23 proteins are cleaved into inactive fragments before secretion, leading to low or undetectable intact FGF23 despite increased FGF23 production [7, 11-13]. This decrease in biologically active intact FGF23 results in increased phosphate reabsorption in the kidney and persistent hyperphosphatemia. Furthermore, low intact FGF23 increases biosynthesis of $1,25(\mathrm{OH})_{2} \mathrm{D}$ and decreases its metabolism, which enhance phosphate and calcium absorption in the small intestine. Thus, this inability to produce sufficient intact FGF23 is the main molecular defect responsible for increased phosphate reabsorption and calcium/phosphate absorption, ultimately leading to ectopic calcifications.

The most common treatment of tumoral calcinosis is surgical resection of recurring massive calcifications. Previously described therapies include dietary phosphate restriction, phosphate binders, and drugs that are thought to be phosphaturic, but these treatments are only limited to single case reports or anecdotes [14-16]. One of those drugs is nicotinamide (also known as niacinamide), which reduces phosphate (re)absorption by decreasing activity of sodium-dependent phosphate co-transporters in both intestine $[17,18]$ and kidney $[19$, 20]. In recent clinical trials, nicotinamide and other niacin derivatives, which block sodiumphosphate co-transport, have seen success in treatment of hyperphosphatemia in patients undergoing dialysis [21-24]. Nicotinamide has been tested in one tumoral calcinosis patient [14]; however, due to the scarcity of patients, its effectiveness in this disorder is still unknown. Therefore, we used a murine model of tumoral calcinosis, Galnt 3 knockout mice [25], to assess the effect of nicotinamide therapy for tumoral calcinosis.

\section{Materials and Methods}

\section{Generation of Experimental Mice}

All experimental mice used in this study were in the C57BL/6 background. Since males homozygous for a Galnt 3 mutation are sterile [25, 26], a heterozygous male and homozygous female were bred to generate experimental mice. Heterozygous mice are phenotypically normal [25], and thus, used in lieu of wild-type mice for nicotinamide dosing study. Homozygous mice were used for a long-term nicotinamide treatment. The study was 
approved by the Indiana University School of Medicine Institutional Animal Care and Use Committee.

\section{Dose Finding in Heterozygous Mice}

Nicotinamide (doses $0,2.5,5,7.5$, and $10 \mathrm{mmol} / \mathrm{kg} /$ day) was administered to six-week-old male and female heterozygotes each day for three consecutive days via intraperitoneal injection. Serum and plasma samples were collected via cardiac puncture one day after the third injection. Heterozygous female mice were also placed on a nicotinamide/acidified water drink mix $(0,10.4,20.8,31.3$, and $41.7 \mathrm{mM}$; ad libitum). These doses are equivalent of those used in the injections, assuming that mice weighed $25 \mathrm{~g}$ and consumed $6 \mathrm{~mL}$ per day [27]. For simplicity, the doses are presented as $0,10,20,30$, and $40 \mathrm{mM}$, respectively. The treatment started when the mice were 8 weeks old and lasted for two weeks. Terminal blood samples were collected via cardiac puncture under anesthesia. Mice were fed Teklad Global 18\% Protein Extruded Rodent Diet (2018SX, Harlan Laboratories, Madison WI), which contained $1.01 \%$ calcium, $0.65 \%$ phosphorus, and $2.05 \mathrm{IU} / \mathrm{g}$ vitamin $\mathrm{D}_{3}$.

\section{Nicotinamide Treatment in a Murine Model of Familial Tumoral Calcinosis}

To induce ectopic calcifications, male and female Galnt 3 knockout mice were placed on a high phosphate diet from weaning at four weeks of age [28]. The high phosphate diet contained $1.65 \%$ phosphorus, $1.0 \%$ calcium, $2.0 \mathrm{IU} / \mathrm{g}$ vitamin $\mathrm{D}_{3}$ (TD.88345, Harlan). After 10 weeks on the diet, a pre-treatment $\mathrm{x}$-ray was taken of lateral and prone positions, using a piXarray 100 Digital Specimen Radiography System with BioPix software. Image acquisition was performed at $24-\mathrm{kV}$ voltage and $0.4 \mathrm{sec}$ exposure time. The mice were then given either acidified water or nicotinamide/acidified water drink mix ( $40 \mathrm{mM}$; ad libitum). After four weeks on the treatment, a post-treatment x-ray of the mice was taken and blood and urine samples were collected.

Kidneys and hearts were also collected to determine phosphate and calcium content. To extract phosphate and calcium, the tissues were minced and submerged in $0.6 \mathrm{~N} \mathrm{HCl}$ solution ( $2.5 \mu \mathrm{L}$ per mg of tissue) for three days under constant, gentle mixing. The supernatant after centrifugation was used for biochemical analysis.

\section{Biochemical Analyses}

Serum, urine, kidney supernatant and heart supernatant were measured using an RX Daytona clinical chemistry analyzer (Randox Laboratories, Crumlin, UK). Parathyroid hormone (PTH) was measured using Mouse PTH 1-84 ELISA kit (Immutopics International, San Clemente, CA). Intact Fgf23 was measured using an Intact Fgf-23 ELISA kit (Kainos Laboratories, Tokyo, Japan). Total Fgf23 levels (intact and C-terminal fragments) were measured, using Mouse FGF-23 (C-Terminal) ELISA kit (Immutopics International).

\section{Statistical Analyses}

Mean and standard error of the mean were calculated for all outcomes according to dosage and sex. Nicotinamide dosing in heterozygous mice were analyzed using ANOVA. Nicotinamide treatment in Galnt3 knockout mice were analyzed using unpaired, two tailed t- 
test between treated mice and same-sex untreated mice. P-values $\$$ (0.05 were considered significant.

\section{Results \\ Dosing Study}

Phenotypically normal heterozygous mice were injected with different doses of nicotinamide for three consecutive days. Nicotinamide reduced intact Fgf23 levels $(\mathrm{p}=0.050$ ) without changing serum phosphorus concentration (data not shown). However, at the higher doses, the animals become inactive and less alert. Therefore, nicotinamide was administered orally mixed in drinking water. In contrast to the i.p. injection, the mice on this treatment remained active and alert regardless of the dose. Body weights of the mice after the treatment were not different between the five groups (data not shown). Despite no change in serum phosphorus, continual nicotinamide decreased intact and total Fgf23 concentrations ( $\mathrm{p}=0.021$ for intact, $\mathrm{p}<0.001$ for total), indicating down-regulation of Fgf 23 as a result of the treatment (Figure 1). Serum PTH was generally lower in mice treated with nicotinamide, but there was no statistically significant difference. Although statistically not significant, urinary phosphate excretion (urinary phosphorus/urinary creatinine ratio) was lower in the animals receiving higher doses. These data suggest that the mice achieved phosphate homeostasis by increasing phosphate reabsorption in the kidney to counter the known phosphate lowering effect of nicotinamide in the gut [17, 18] and kidney [19, 20].

\section{Nicotinamide Treatment of a Murine Model of Familial Tumoral Calcinosis}

To induce ectopic calcifications, Galnt 3 knockout mice were fed the high phosphate diet for 10 weeks. Given the higher phosphate content of the diet, we utilized the highest dose tested in the heterozygous mice $(40 \mathrm{mM})$ for treatment of this animal model. As expected, serum phosphorus in Galnt 3 knockout mice was higher than that in heterozygotes in the dosing study. In an attempt to produce more intact Fgf23 in the face of increased proteolysis, Galnt3 knockout mice also produced markedly higher total Fgf23, compared to heterozygous mice. Similar to the dosing study, serum phosphate did not differ greatly between control and treated groups, and no gender difference was observed (Figure 2). Urine phosphate (and calcium) in the treated mice showed a trending increase, despite lower intact Fgf23 levels, but neither males nor females reached statistical significance.

Nicotinamide treatment did not affect serum PTH levels although treated males had slightly lower PTH than untreated. However, it lowered intact Fgf 23 dramatically in both males and females (males, $\mathrm{p}=0.041$; females, $\mathrm{p}<0.001$ ), comparable to the effect observed in heterozygotes.

Nicotinamide treatment slightly reduced total Fgf23 levels only in treated males. Serum alkaline phosphatase was markedly elevated in treated female mice $\left(\mathrm{p}<10^{-6}\right)$, while treated males maintained their alkaline phosphatase. Blood urine nitrogen (BUN) was significantly higher only in treated females. Female mice on the treatment also experienced a significant drop in weight ( 11\%), while male mouse weight dipped only slightly (data not shown). 
At the start of the treatment, the high phosphate diet induced ectopic calcifications visible on radiographs, reminiscent of tumoral calcinosis, in four mutant mice. Two were treated with nicotinamide, and the other two were not treated. Although the treatment did not eliminate calcifications, radiographs showed no apparent increase in calcification sizes in the treated mice (Figure 3). In contrast, the calcifications in the untreated mice became visibly larger. Furthermore, one additional mouse developed calcification in the tongue when it remained on the high phosphate diet without treatment, whereas the number of mice with calcifications did not change for the treated group.

To determine whether accumulated calcium-phosphate products were released from extraskeletal tissues, we measured calcium and phosphate levels in the heart and kidney. Phosphate in treated groups paralleled the control groups, but a dramatic increase was seen in heart tissue calcium, reaching statistical significance in females ( $\mathrm{p}<0.01)$ (Figure 4). The same trend was also seen in males, despite a smaller sample size $(\mathrm{p}=0.13)$.

\section{Discussion}

Nicotinamide (and other niacin derivatives) suppresses sodium-phosphate cotransport in the gut $[17,18]$ and kidney $[19,20]$. Given the physiologic effect of nicotinamide, it is a potential therapy for familial tumoral calcinosis. However, due to insufficient observations in humans, the effectiveness of nicotinamide in tumoral calcinosis remains unclear. To test this potential treatment, we used a murine model of this disorder. Regardless of genotypes or delivery route, nicotinamide significantly decreased serum Fgf23 concentrations. Since nicotinamide reduces intestinal absorption and/or renal reabsorption, it would likely limit cellular uptake of phosphate by osteocytes, the source of Fgf23. As a result of this compensatory response to nicotinamide, the treatment had no net effect on serum phosphate levels. Similarly, one tumoral calcinosis patient treated with nicotinamide had increased phosphate excretion, accompanied by lower Fgf23 [14]. This normal response to changing phosphate likely reduces the efficacy of nicotinamide as a therapy in blocking the sodium phosphate transport.

Although serum phosphate was unchanged in heterozygous mice, nicotinamide treatment in the murine model of tumoral calcinosis was pursued because these animals may respond differently due to their inability to make sufficient intact Fgf23. Similar to the heterozygous mice, high-dose nicotinamide treatment reduced intact Fgf23, resulting in no net change in serum phosphate. However, in contrast to decreased phosphate excretion in heterozygous mice at the high doses, Galnt 3 knockout mice had a trend for increased urinary phosphate excretion. These data suggest that the mutant mice may be maximally reabsorbing phosphate by lowering intact Fgf23, but excess phosphate (and calcium) presumably released from the extraskeletal tissues are still excreted in urine. We cannot exclude the possibility that the higher phosphate load in Galnt3 knockout mice led to increased urinary phosphate excretion.

In tumoral calcinosis, persistent hyperphosphatemia results in ectopic calcifications in soft tissues. Comparison of pre- and post- treatment radiographs showed that nicotinamide may not clear calcifications, but likely slow down calcification progression and prevent further 
calcification from occurring. After ten weeks of depositing phosphate into tissues, four weeks of treatment may have been insufficient for completely resolving the calcifications. Alternatively, once formed, the calcification may not be able to be lysed. It is also possible that the high phosphate diet was too much to overcome with the dose used in this study. Although nicotinamide could not eliminate calcifications, increasing urinary excretion and slowing of calcification process suggests nicotinamide may be effective in the treatment of tumoral calcinosis. However, while the treatment did not alter phosphate content in the kidneys and hearts, an unexpected rise in heart tissue calcium is a concern. The physiological consequences of elevated heart calcium are uncertain, but it likely has negative implications for cardiovascular health [29]. The finding is relevant to other studies using nicotinamide to control hyperphosphatemia, particularly clinical trials for hemodialysis patients. However, in the general population, niacin appears to have cardioprotective effects [30]. Use of niacin has led to reduced cardiovascular events, not increased events which would be expected if the increased calcification was pathologic. We have no explanation for this unexpected observation, especially since phosphate content of the tissue was not simultaneously increased, suggesting that the calcium may have deposited with other anions. Further studies are required to discern the mechanism and consequences of such a finding.

In general, nicotinamide had greater impact on female Galnt3 knockout mice. Serum alkaline phosphatase was markedly higher in treated females, compared to males. Galnt3 knockout mice have lower alkaline phosphatase [25, 26], but nicotinamide essentially normalized alkaline phosphatase in the treated females, possibly as an early sign of improving serum phosphorus. The increment in BUN was only significant in treated females. Female mice on the treatment also lost body weight, while the drug had no effect on weight of males. Since water consumption is expected to be proportional to body size with no gender effect, it is possible that nicotinamide is metabolized at the different rates between males and females and has higher potency in females.

\section{Conclusion}

Heterozygous mice administered with nicotinamide experienced a significant decrease in Fgf23 to compensate for suppression of phosphate absorption in the gut and reabsorption in the kidney by nicotinamide. Similarly, Galnt3 knockout mice lowered Fgf23, which perpetuated the hyperphosphatemic phenotype and failed to remove ectopic calcifications. Although this compensatory reduction in Fgf 23 reduces the effectiveness of nicotinamide, the radiographic evidence suggests that nicotinamide may retard calcification progress. Increased heart calcium due to the treatment is concerning. However, nicotinamide remains a viable treatment option for mild tumoral calcinosis. Clinical studies are needed to confirm the translational potential of these findings.

\section{Acknowledgments}

We thank Anthony Acton for performing biochemical measurements. This study was supported by Indiana University School of Medicine Life-Health Sciences Internship (to AMR), Indiana CTSI Summer Internship (to AMR), National Institutes of Health grant R01 AR058005 (SMM), and KL2 career development award (to SI) from the Indiana Clinical and Translational Sciences Institute funded in part by the National Institutes of Health grant KL2 RR025760. 


\section{Abbreviations}
FGF23
fibroblast growth factor 23
GALNT3
GalNAc transferase 3
$1,25(\mathrm{OH})_{2} \mathrm{D}$
1,25-dihydroxyvitamin D

\section{References}

1. Topaz O, Shurman DL, Bergman R, Indelman M, Ratajczak P, Mizrachi M, Khamaysi Z, Behar D, Petronius D, Friedman V, Zelikovic I, Raimer S, Metzker A, Richard G, Sprecher E. Mutations in GALNT3, encoding a protein involved in O-linked glycosylation, cause familial tumoral calcinosis. Nat Genet. 2004; 36:579-81. [PubMed: 15133511]

2. Ichikawa S, Baujat G, Seyahi A, Garoufali AG, Imel EA, Padgett LR, Austin AM, Sorenson AH, Pejin Z, Topouchian V, Quartier P, Cormier-Daire V, Dechaux M, Malandrinou F, Singhellakis PN, Le Merrer M, Econs MJ. Clinical variability of familial tumoral calcinosis caused by novel GALNT3 mutations. Am J Med Genet A. 2010; 152A:896-903. [PubMed: 20358599]

3. Ichikawa S, Lyles KW, Econs MJ. A novel GALNT3 mutation in a pseudoautosomal dominant form of tumoral calcinosis: evidence that the disorder is autosomal recessive. J Clin Endocrinol Metab. 2005; 90:2420-3. [PubMed: 15687324]

4. Ichikawa S, Imel EA, Kreiter ML, Yu X, Mackenzie DS, Sorenson AH, Goetz R, Mohammadi M, White KE, Econs MJ. A homozygous missense mutation in human KLOTHO causes severe tumoral calcinosis. J Clin Invest. 2007; 117:2684-91. [PubMed: 17710231]

5. Benet-Pagès A, Orlik P, Strom TM, Lorenz-Depiereux B. An FGF23 missense mutation causes familial tumoral calcinosis with hyperphosphatemia. Hum Mol Genet. 2005; 14:385-90. [PubMed: 15590700]

6. Larsson T, Yu X, Davis SI, Draman MS, Mooney SD, Cullen MJ, White KE. A novel recessive mutation in fibroblast growth factor-23 causes familial tumoral calcinosis. J Clin Endocrinol Metab. 2005; 90:2424-7. [PubMed: 15687325]

7. Kato K, Jeanneau C, Tarp MA, Benet-Pages A, Lorenz-Depiereux B, Bennett EP, Mandel U, Strom TM, Clausen H. Polypeptide GalNAc-transferase T3 and familial tumoral calcinosis. Secretion of fibroblast growth factor 23 requires O-glycosylation. J Biol Chem. 2006; 281:18370-7. [PubMed: 16638743]

8. Kurosu H, Ogawa Y, Miyoshi M, Yamamoto M, Nandi A, Rosenblatt KP, Baum MG, Schiavi S, Hu MC, Moe OW, Kuro-o M. Regulation of fibroblast growth factor-23 signaling by klotho. J Biol Chem. 2006; 281:6120-3. [PubMed: 16436388]

9. Urakawa I, Yamazaki Y, Shimada T, Iijima K, Hasegawa H, Okawa K, Fujita T, Fukumoto S, Yamashita T. Klotho converts canonical FGF receptor into a specific receptor for FGF23. Nature. 2006; 444:770-4. [PubMed: 17086194]

10. Shimada T, Mizutani S, Muto T, Yoneya T, Hino R, Takeda S, Takeuchi Y, Fujita T, Fukumoto S, Yamashita T. Cloning and characterization of FGF23 as a causative factor of tumor-induced osteomalacia. Proc Natl Acad Sci U S A. 2001; 98:6500-5. [PubMed: 11344269]

11. Ichikawa S, Guigonis V, Imel EA, Courouble M, Heissat S, Henley JD, Sorenson AH, Petit B, Lienhardt A, Econs MJ. Novel GALNT3 mutations causing hyperostosis-hyperphosphatemia syndrome result in low intact fibroblast growth factor 23 concentrations. J Clin Endocrinol Metab. 2007; 92:1943-7. [PubMed: 17311862]

12. Ichikawa S, Imel EA, Sorenson AH, Severe R, Knudson P, Harris GJ, Shaker JL, Econs MJ. Tumoral calcinosis presenting with eyelid calcifications due to novel missense mutations in the glycosyl transferase domain of the GALNT3 gene. J Clin Endocrinol Metab. 2006; 91:4472-5. [PubMed: 16940445]

13. Bergwitz C, Banerjee S, Abu-Zahra H, Kaji H, Miyauchi A, Sugimoto T, Juppner H. Defective Oglycosylation due to a novel homozygous S129P mutation is associated with lack of fibroblast 
growth factor 23 secretion and tumoral calcinosis. J Clin Endocrinol Metab. 2009; 94:4267-74. [PubMed: 19837926]

14. Dumitrescu CE, Kelly MH, Khosravi A, Hart TC, Brahim J, White KE, Farrow EG, Nathan MH, Murphey MD, Collins MT. A case of familial tumoral calcinosis/hyperostosis-hyperphosphatemia syndrome due to a compound heterozygous mutation in GALNT3 demonstrating new phenotypic features. Osteoporos Int. 2009; 20:1273-8. [PubMed: 18982401]

15. Garringer HJ, Fisher C, Larsson TE, Davis SI, Koller DL, Cullen MJ, Draman MS, Conlon N, Jain A, Fedarko NS, Dasgupta B, White KE. The role of mutant UDP-N-acetyl-alpha-Dgalactosamine-polypeptide $\mathrm{N}$-acetylgalactosaminyltransferase 3 in regulating serum intact fibroblast growth factor 23 and matrix extracellular phosphoglycoprotein in heritable tumoral calcinosis. J Clin Endocrinol Metab. 2006; 91:4037-42. [PubMed: 16868048]

16. Yamaguchi T, Sugimoto T, Imai Y, Fukase M, Fujita T, Chihara K. Successful treatment of hyperphosphatemic tumoral calcinosis with long-term acetazolamide. Bone. 1995; 16:247S-250S. [PubMed: 7626311]

17. Eto N, Miyata Y, Ohno H, Yamashita T. Nicotinamide prevents the development of hyperphosphataemia by suppressing intestinal sodium-dependent phosphate transporter in rats with adenine-induced renal failure. Nephrol Dial Transplant. 2005; 20:1378-84. [PubMed: 15870221]

18. Katai K, Tanaka H, Tatsumi S, Fukunaga Y, Genjida K, Morita K, Kuboyama N, Suzuki T, Akiba T, Miyamoto K, Takeda E. Nicotinamide inhibits sodium-dependent phosphate cotransport activity in rat small intestine. Nephrol Dial Transplant. 1999; 14:1195-201. [PubMed: 10344361]

19. Wu KI, Bacon RA, Al-Mahrouq HA, Kempson SA. Nicotinamide as a rapid-acting inhibitor of renal brush-border phosphate transport. Am J Physiol. 1988; 255:F15-21. [PubMed: 2839989]

20. Kempson SA, Colon-Otero G, Ou SY, Turner ST, Dousa TP. Possible role of nicotinamide adenine dinucleotide as an intracellular regulator of renal transport of phosphate in the rat. J Clin Invest. 1981; 67:1347-60. [PubMed: 6453134]

21. Cheng SC, Young DO, Huang Y, Delmez JA, Coyne DW. A randomized, double-blind, placebocontrolled trial of niacinamide for reduction of phosphorus in hemodialysis patients. Clin J Am Soc Nephrol. 2008; 3:1131-8. [PubMed: 18385391]

22. Takahashi Y, Tanaka A, Nakamura T, Fukuwatari T, Shibata K, Shimada N, Ebihara I, Koide H. Nicotinamide suppresses hyperphosphatemia in hemodialysis patients. Kidney Int. 2004; 65:1099104. [PubMed: 14871431]

23. Young DO, Cheng SC, Delmez JA, Coyne DW. The effect of oral niacinamide on plasma phosphorus levels in peritoneal dialysis patients. Perit Dial Int. 2009; 29:562-7. [PubMed: 19776051]

24. Shahbazian H, Zafar Mohtashami A, Ghorbani A, Abbaspour MR, Belladi Musavi SS, Hayati F, Lashkarara GR. Oral nicotinamide reduces serum phosphorus, increases HDL, and induces thrombocytopenia in hemodialysis patients: a double-blind randomized clinical trial. Nefrologia. 2011; 31:58-65. [PubMed: 21270914]

25. Ichikawa S, Sorenson AH, Austin AM, Mackenzie DS, Fritz TA, Moh A, Hui SL, Econs MJ. Ablation of the Galnt3 gene leads to low-circulating intact fibroblast growth factor 23 (Fgf23) concentrations and hyperphosphatemia despite increased Fgf23 expression. Endocrinology. 2009; 150:2543-50. [PubMed: 19213845]

26. Ichikawa S, Austin AM, Gray AK, Allen MR, Econs MJ. Dietary phosphate restriction normalizes biochemical and skeletal abnormalities in a murine model of tumoral calcinosis. Endocrinology. 2011; 152:4504-13. [PubMed: 22009723]

27. Bachmanov AA, Reed DR, Beauchamp GK, Tordoff MG. Food intake, water intake, and drinking spout side preference of 28 mouse strains. Behav Genet. 2002; 32:435-43. [PubMed: 12467341]

28. Ichikawa S, Gray AK, Padgett LR, Reilly AM, Unsicker TR. High Dietary Phosphate Intake Induces Development of Ectopic Calcifications in a Murine Model of Familial Tumoral Calcinosis. J Bone Miner Res. 2014

29. Budoff MJ, Young R, Lopez VA, Kronmal RA, Nasir K, Blumenthal RS, Detrano RC, Bild DE, Guerci AD, Liu K, Shea S, Szklo M, Post W, Lima J, Bertoni A, Wong ND. Progression of 
coronary calcium and incident coronary heart disease events: MESA (Multi-Ethnic Study of Atherosclerosis). J Am Coll Cardiol. 2013; 61:1231-9. [PubMed: 23500326]

30. Julius U, Fischer S. Nicotinic acid as a lipid-modifying drug--a review. Atheroscler Suppl. 2013; 14:7-13. [PubMed: 23357134] 


\section{Highlights}

- Oral nicotinamide did not alter serum phosphate; however, it reduced serum Fgf23 concentrations.

- Although nicotinamide treatment did not remove ectopic calcification, it appears to retard progression of calcification.

- Galnt3 knockout mice treated with nicotinamide had significantly higher calcium in the heart. 

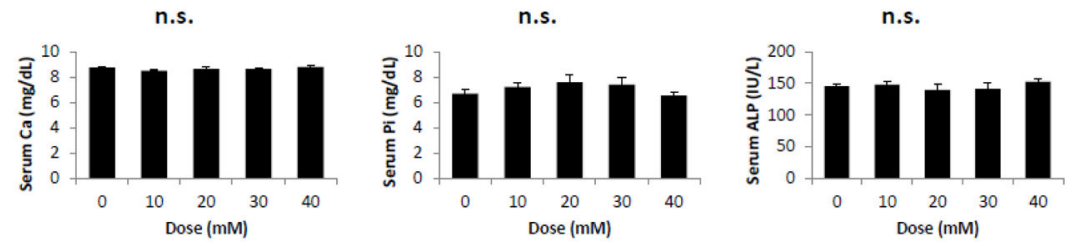

n.s.

$P=0.021$

$\mathrm{P}<0.001$
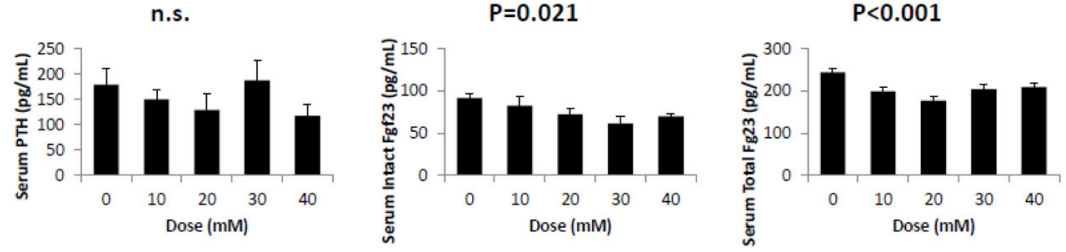

$P=0.004$

n.s.

n.s.
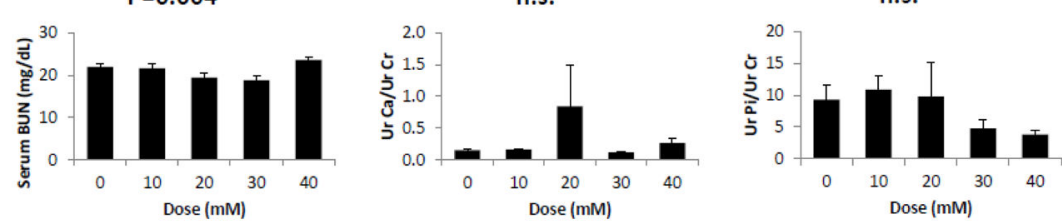

Figure 1.

Administration of nicotinamide in drinking water. Nicotinamide was infused in drinking water to treat heterozygous females. While nicotinamide did not change serum phosphorus, it had a significant effect on serum Fgf23 levels. Each column represents the mean \pm SEM. $\mathrm{N}=8-12$ for serum measurements; $\mathrm{N}=3-6$ for urine measurements. ANOVA p-values between the five groups are shown above each graph. N.S., not significant; $\mathrm{Ca}$, calcium; Pi, phosphorus; ALP, alkaline phosphatase; BUN, blood urine nitrogen; $\mathrm{Ur}$, urine; $\mathrm{Cr}$, creatinine. 

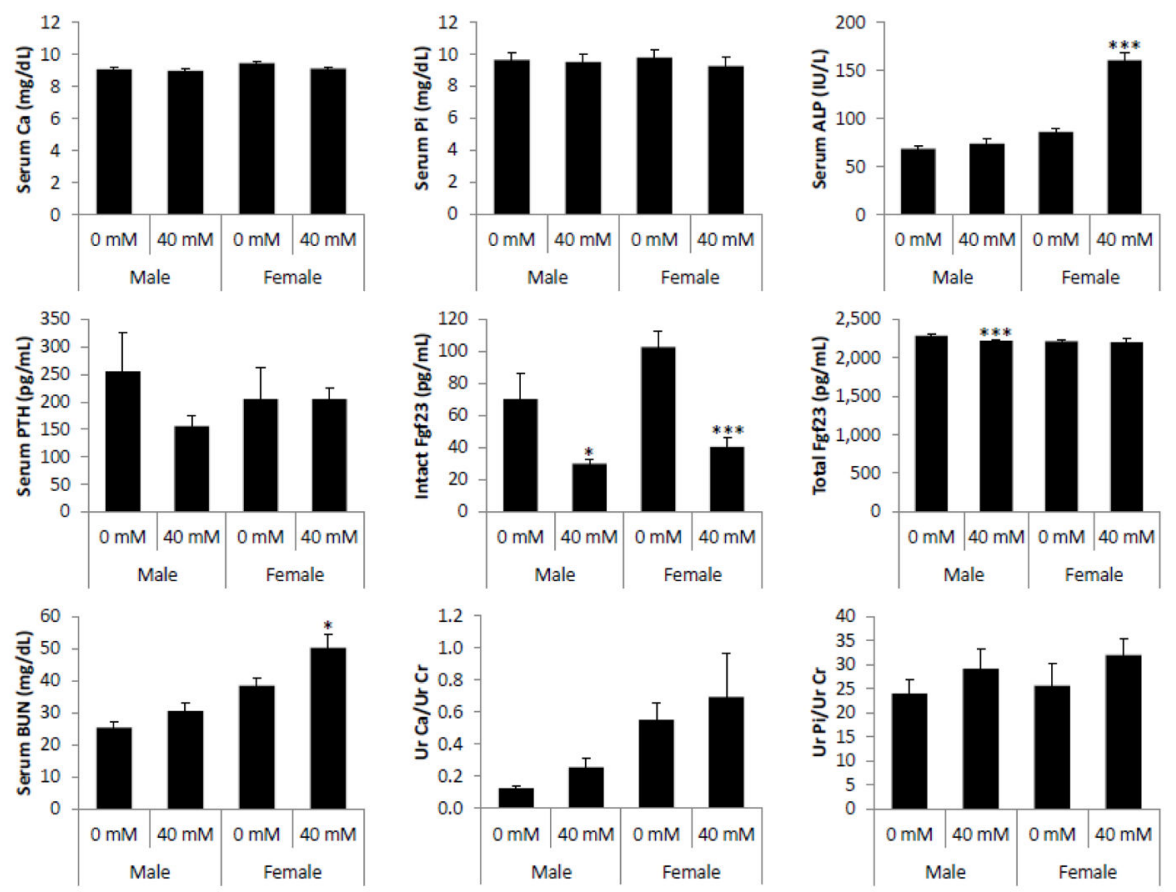

Figure 2.

Nicotinamide treatment of Galnt 3 knockout mice. Galnt3 knockout mice were fed a high phosphate diet for 10 weeks, followed by 4 weeks on nicotinamide infused drinking water. Intact Fgf23 decreased significantly in treated males and females; however, total Fgf23 decreased only in males. Each column represents the mean \pm SEM. $N=8-12$ for serum measurements, $\mathrm{N}=5-8$ for urine measurements. T-test $\mathrm{P}<0.05^{*}$ and $\mathrm{P}<0.01^{* * *}$, compared to sex-matched controls. Ca, calcium; Pi, phosphorus; ALP, alkaline phosphatase; BUN, blood urine nitrogen; $\mathrm{Ur}$, urine; $\mathrm{Cr}$, creatinine. 


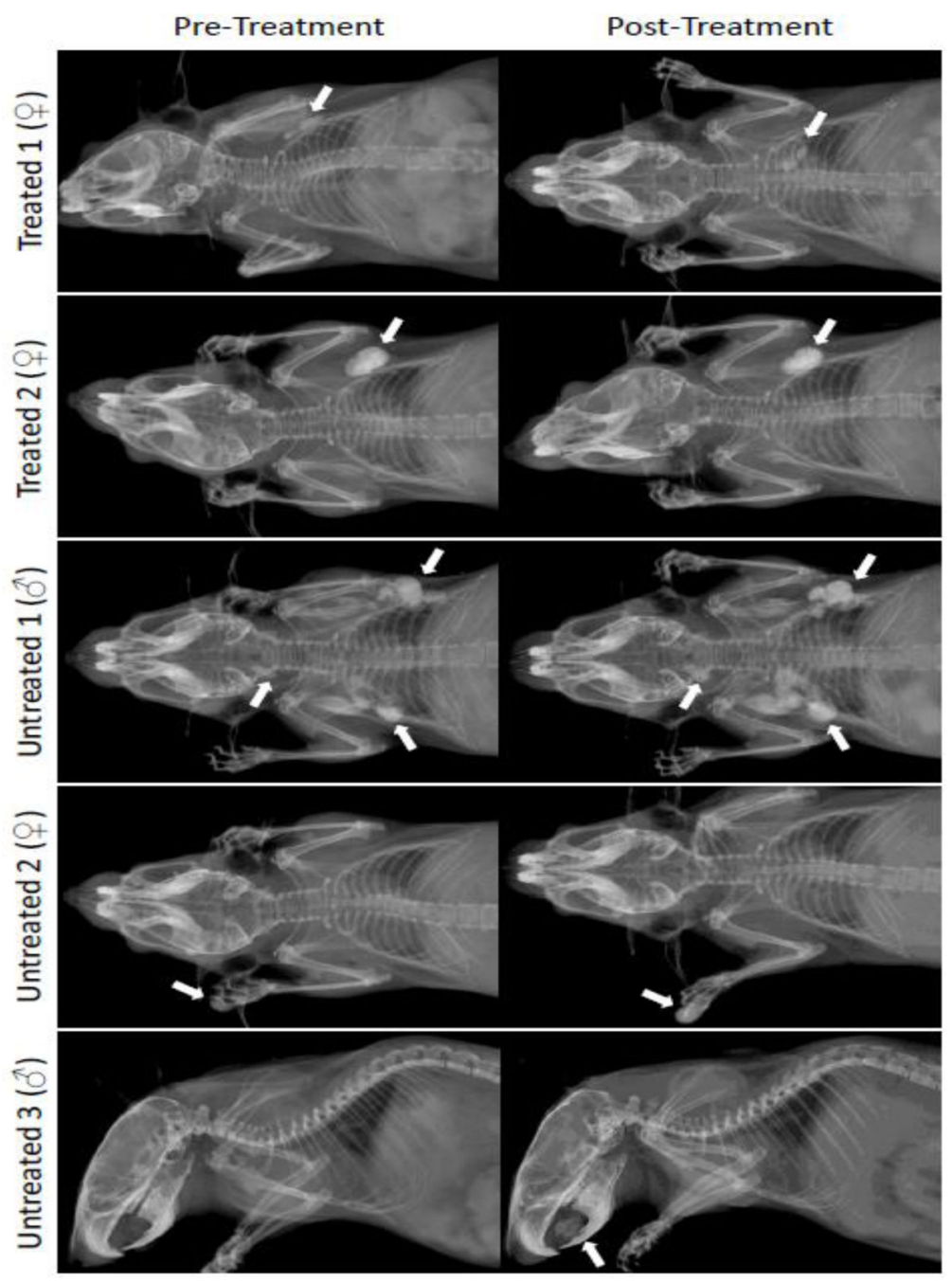

Figure 3.

Effect of nicotinamide on ectopic calcifications in Galnt3 knockout mice. After ten weeks of the high phosphate diet, four Galnt 3 knockout mice developed well-defined ectopic calcifications (white arrows). Two were treated with approximately $40 \mathrm{mM}$ of nicotinamide, and the other two were untreated. While calcifications in the untreated mice (Untreated 1 and 2) became larger, more radiodense, or interconnected, there was no clear increase in the calcification sizes in the treated mice (Treated 1 and 2). Furthermore, an additional untreated mouse (Untreated 3) developed calcification in the tongue, which was not apparent in the pre-treatment radiograph. 

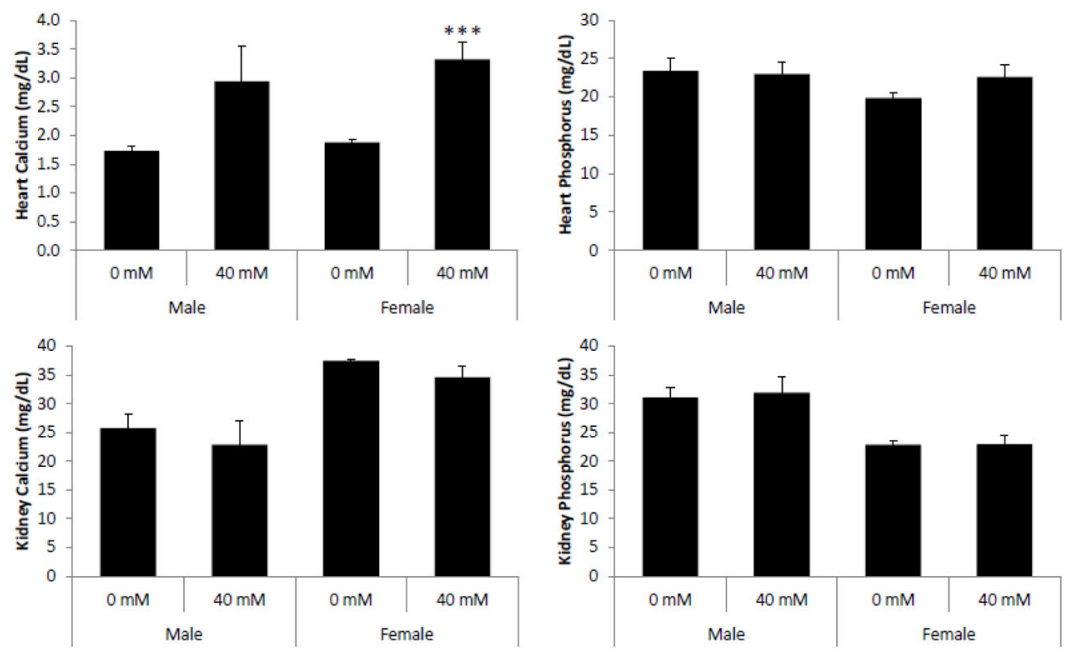

Figure 4.

Effects of nicotinamide treatment on kidney and heart tissues in Galnt3 knockout mice.

Calcium and phosphorus in the kidney were not affected; however, calcium in the heart was significantly higher in the treated females. Each column represents the mean $\pm \mathrm{SEM}$. N=712 for kidney measures and $\mathrm{N}=4-9$ in heart measures. T-test $\mathrm{P}<0.01^{* * *}$, compared to samesex control group. 